\title{
Mapping the Migratory Movements
}

Cartographier les mouvements migratoires

Cartografiar los movimientos migratorios

Lucie Bacon, Olivier Clochard, Thomas Honoré, Nicolas Lambert, Sarah Mekdjian and Philippe Rekacewicz

Translator. Alexandra Pomeon

\section{(2) OpenEdition}

12 Journals

\section{Electronic version}

URL: https://journals.openedition.org/remi/8803

DOI: $10.4000 /$ remi.8803

ISSN: $1777-5418$

This article is a translation of:

Cartographier les mouvements migratoires - URL : https://journals.openedition.org/remi/8249 [fr]

\section{Publisher}

Université de Poitiers

Printed version

Date of publication: 1 December 2016

ISBN: 979-10-90426-29-0

ISSN: 0765-0752

\section{Electronic reference}

Lucie Bacon, Olivier Clochard, Thomas Honoré, Nicolas Lambert, Sarah Mekdjian and Philippe Rekacewicz, "Mapping the Migratory Movements", Revue européenne des migrations internationales [Online], vol. 32 - n³ et 4 | 2016, Online since 01 December 2018, connection on 14 April 2022. URL: http://journals.openedition.org/remi/8803 ; DOI: https://doi.org/10.4000/remi.8803 


\title{
Mapping the Migratory Movements
}

\author{
Cartographier les mouvements migratoires \\ Cartografiar los movimientos migratorios \\ Lucie Bacon, Olivier Clochard, Thomas Honoré, Nicolas Lambert, Sarah
Mekdjian and Philippe Rekacewicz
}

Translation : Alexandra Pomeon

Mapping migratory movements, which means "immobilising" a complex spatial, temporal, social and political system, presents major challenges. Not only do individuals migrating or fleeing cross paths, they also "take breaks" of varying durations, settle temporarily in a country or a place for several days, weeks or years and sometimes move again. The geography and cartography of migration are subject to time as well as political developments, which may be very rapid. Thus, mapping always runs the risk of being outdated before the map is even finished. Furthermore, the measurement of "flows" requires migration to be analysed by aggregating data, which is both spatial and temporal and may be processed in very different ways. The general term "flows", used in the titles of numerous migration maps, is rarely explained. Thus, a migration flow may be measured on the basis of the number of crossings at a particular point during a given time period (for example, the number of people who crossed the border between Mexico and the United States at Ciudad Juarez in 2015); it can also be measured between two points (the number of people who departed from Chiapas in Mexico and arrived in California in 2015). In the first instance, it is a question of counting movements which are in the process of taking place and calculating them at a precise point; in the second case, movement is reconstructed $a$ posteriori on the basis of absolute quantitative data (the "stock" of Mexican people from Chiapas identified in California since 2015). Maps also cover individual movements, which are no longer labelled "flows" but "routes" or "journeys", combining spatial data with social, political and/or temporal data ${ }^{1}$. Presenting the complexity of temporal data through cartography, which is based on spatial analogy, is a broad area of research which has produced technical and epistemological innovations, in particular static choremes, followed by dynamic choremes, animated computerised maps, some of which are interactive (Kaddouri, 2008). 
2 In addition to the challenge of representing movement, it can be very hard to access statistical data in the area of migration study. The statistical tools at our disposal ${ }^{2}$ are often incomplete, imprecise or even based on questionable methods. Nevertheless, significant qualitative progress has been made since the beginning of the 2000s, driven in particular by the development of data journalism ${ }^{3}$. In order to map migration processes, on various scales, it is necessary to "generalise" and process available data in "batches", i.e. to summarise the available information to depict key trends, where it is not possible to quantify information precisely. In conjunction with this area of work, many researchers conduct field work and use "fine scale" mapping as an analytical tool to understand the processes taking place in camps, reception facilities, stations, airports, towns and neighbourhoods. Participatory initiatives open to civil society, outside uniquely academic circles, such as Close the camps ${ }^{4}$, Migrants files and Watch the Med, provide a means of collecting quantitative and qualitative data, thanks to people gathering disparate information ${ }^{5}$. These methods of generating knowledge, which are still under development, are particularly promising.

3 As well as consideration of temporalities in the cartography of migration, and the need to collect verifiable data, there are specific representation challenges in cartography. A map, as a "visual message" which may be fictional and/or a reference tool, is "iconotext" (Cosgrove, 2001, p. 148), a set of graphic symbols, defined by characteristics of shape, size or colour, to which meaning is ascribed: arrows, squares, circles, lines which on a map symbolise refugees, camps, crossing points, walls or borders. The key explaining the main components of a map employs unique grammar and semiology. Maps of migration flows, which are very often designed on the basis of the arrow symbol, are the best-known models depicting and formally expressing spatio-temporal data on migration. In the case of reference maps, representing reality through symbols, with arrows, carries risks. Any choice of graphic, which is inevitably subjective, even when inspired by established language like the graphic semiology developed by Bertin (1967), can lead to interpretations that are out of step with, or even contrary to, the intentions of the cartographer: the use of arrows which are too thick, pointing in the same direction, risks evoking (or suggesting more or less unconsciously) an "invasion"; circles which are too small and hardly visible may convey a denial of recognition of a significant population in a camp. Thus, on the basis of a study of maps of trans-Saharan migration in the media, Armelle Choplin and Olivier Pliez criticise the construction of a "smooth migration area, in which the use of continuous lines to represent several migration routes conceals all the rough patches - of a spatial and temporal nature, based on political, police or financial factors - which punctuate migrants' journeys (Choplin and Pliez, 2011). Indeed, one of the challenges in the cartography of migration, supplementing quantitive and aggregated approaches to mobility, is how to represent movement in a qualitative and sensitive way, particularly from the point of view of those who move. Emphasising the tendency of migration maps to reductionism, dehumanisation and depoliticisation of migration contexts, the two authors also underline the risk that some "media maps" may confuse "routes" and "flows", fuelling anxiety of an "invasion": "The long lines depicting African migration to Europe convey a slightly worrying image of an invasion via routes (Ceuta and Melilla, Libya, etc.) which are rarely taken simultaneously by thousands of migrants. These maps cause it to be forgotten that such flows are marginal within African migration and even transSaharan migration" (ibid.). The scientific, representational and political challenges to be faced in the cartography of migratory movements include Euro-centrism, or more 
generally the reproduction of a divide between "North" and "South"; the choice of standardised base maps which replicate the political fantasy of linear and fixed borders; and the reduction of movement to arrows or stock measurements.

Another risk presented by the cartography of migration is connected to the use of state mechanisms and supra-state mechanisms to monitor and chart movements of populations and individuals. Indeed, geographic information systems, GPS and mapping in general are tools that support control and exclusion policies. In the area of science, it is therefore important to question the potential uses of the maps produced, outside the academic context, and to explore the connections between the generation of knowledge and politics. Here the ethics of representation are at stake, in relation to conflicting political and ideological contexts.

On the basis of an analysis of past and present cartography of migration flows, from diverse sectors - science, art, activism - and various continental, regional and national contexts, we will examine some of the main technical, ethical, institutional and political challenges raised by cartographic representation of international migration. We will attempt to provide a critical analysis, both of the role of cartography in the generation of knowledge about migration, and its socially and politically transformative potential.

6 The first part of this article will chart the main developments in scientific cartography of migration movements, from its origins in the 19th century to the present, in order to identify and analyse the main technical, epistemological and political challenges that it continues to raise, in the second part of the article. Finally, we set out a typology of creative and interdisciplinary migration maps at the intersection between science, art and activism.

\section{Representing Migration Flows: Developments and Challenges}

7 The first maps of migration flows emerged in the 19th century, with the birth of modern thematic cartography using demographic, sociological and economic statistics. However, such cartography became more widely used much later, at the end of the 1980s, when migration became a research subject.

\section{Migration Takes Place but Few Maps represent it}

8 According to Françoise Bahoken (2013, p. 2), the map "Currents of Migration" published in 1885, produced "by Ernst Georg Ravenstein, a German geographer and cartographer from the Royal Geographic Society (RGS), London... seems to be the first map of flows produced using arrows". This map does not depict a hierarchy between flows and is based on a qualitative approach to internal mobility ${ }^{6}$ in the United Kingdom, Great Britain and Ireland. Another map produced in the 19th century ${ }^{7}$ shows the migration of agricultural workers in European Russia towards the southern regions: the Black Sea and the Caspian Sea (see Map 1).

9 While international migration in the 19th century was characterised by very significant migration flows ${ }^{8}$ and statistical mapping made well known advances between 1835 and 1855 with "various representation techniques... including movements" (Robinson, 1955, 
p. 1 in Bahoken, 2013, p. 5), migration maps remained scarce. Only the map by CharlesJoseph Minard, approximately and without using arrows, represents migration on a global scale in 1858 (Map 1) $)^{9}$.

\section{Map 1: Figurative and Approximate Map Showing Emigrants of the World for the Year 1858}

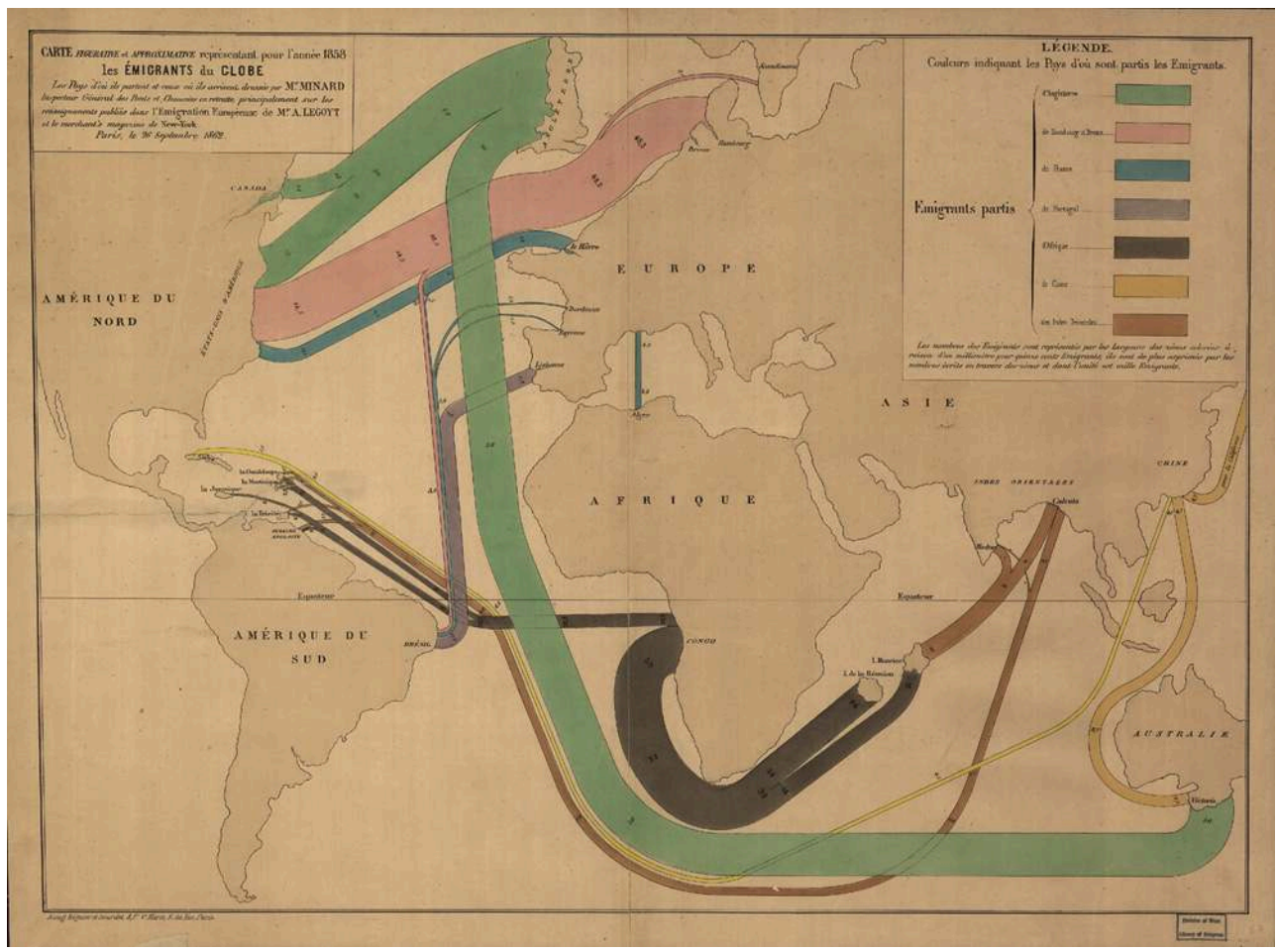

Source: https://cartographia.wordpress.com/category/charles-joseph-minard/

Credit: Cartographia. Mapping The World Around You, Archive for the 'Charles Joseph Minard' Category, 2008.

An overview of various books and atlases published at the turn of the $20^{\text {th }}$ century ${ }^{10}$, reveals some documents - focused on more localised processes - which use arrows as features of maps. As examples, we can point to the maps by René Avelot designed in 1905 depicting the main migration in French Gabon and Congo (Avelot, 1905), as well as that by Jovan Cvijić, published in 1918, representing the movement of populations inhabiting parts of the Serbian countries from the 15th century to the beginning of the 20th century (Cvijié, 1918). However, in atlases, flows are more often represented on maps showing economic data on a global scale, and we see transfers of coffee, tea and cereal (wheat from Argentina, the United States or Canada to Europe) followed several pages later - by transfers of global industrial production (materials, metallurgy, etc.) (Schrader and Gallouédec, 1923) (see Map 2). 
Map 2: Global Land Production

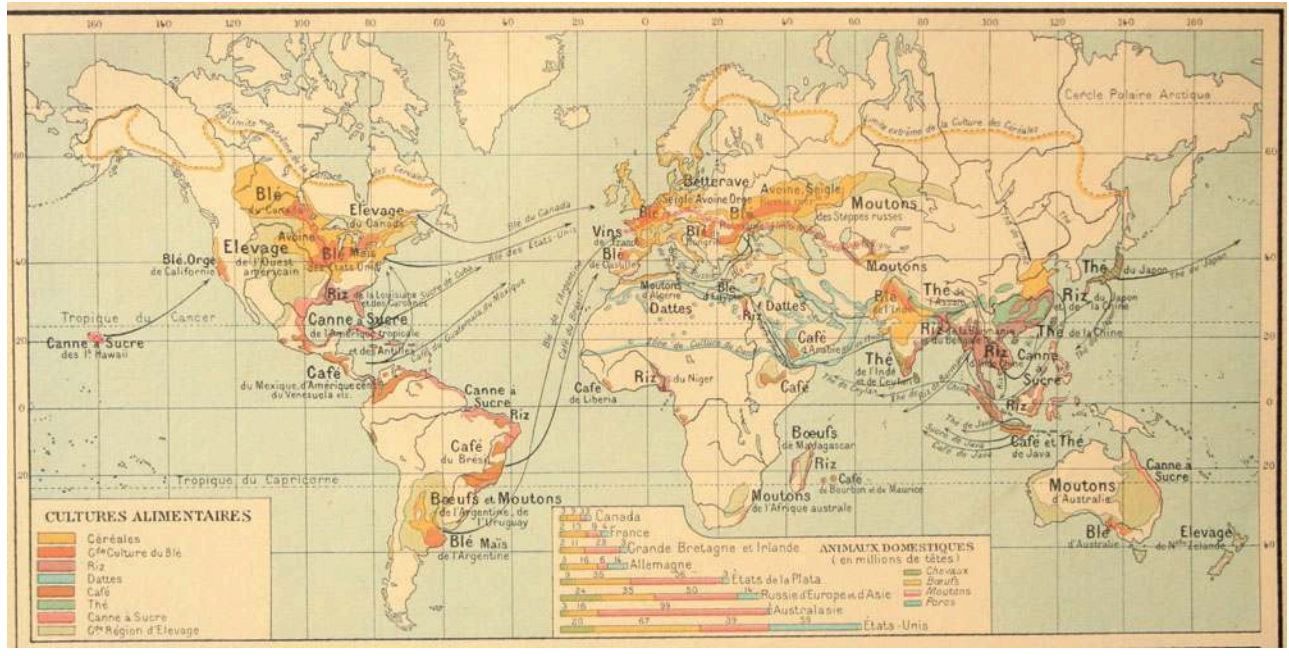

Source: Schrader F. and Gallouédec L. (1923) Atlas classique de géographie ancienne et moderne, Paris, Hachette, p. 123

11 The lack of representation of human flows is essentially due to political factors: representing the main European migration flows would have meant highlighting "developed" societies in crisis. Thus the spatial structure of economic exchanges between pairs of places of origin (i) and destination ( $j$ ) was the main subject in the cartography of flows until the 1980s, when studies on contemporary international migration developed.

Contemporary Maps of Flows (Over)estimating Migration Processes 


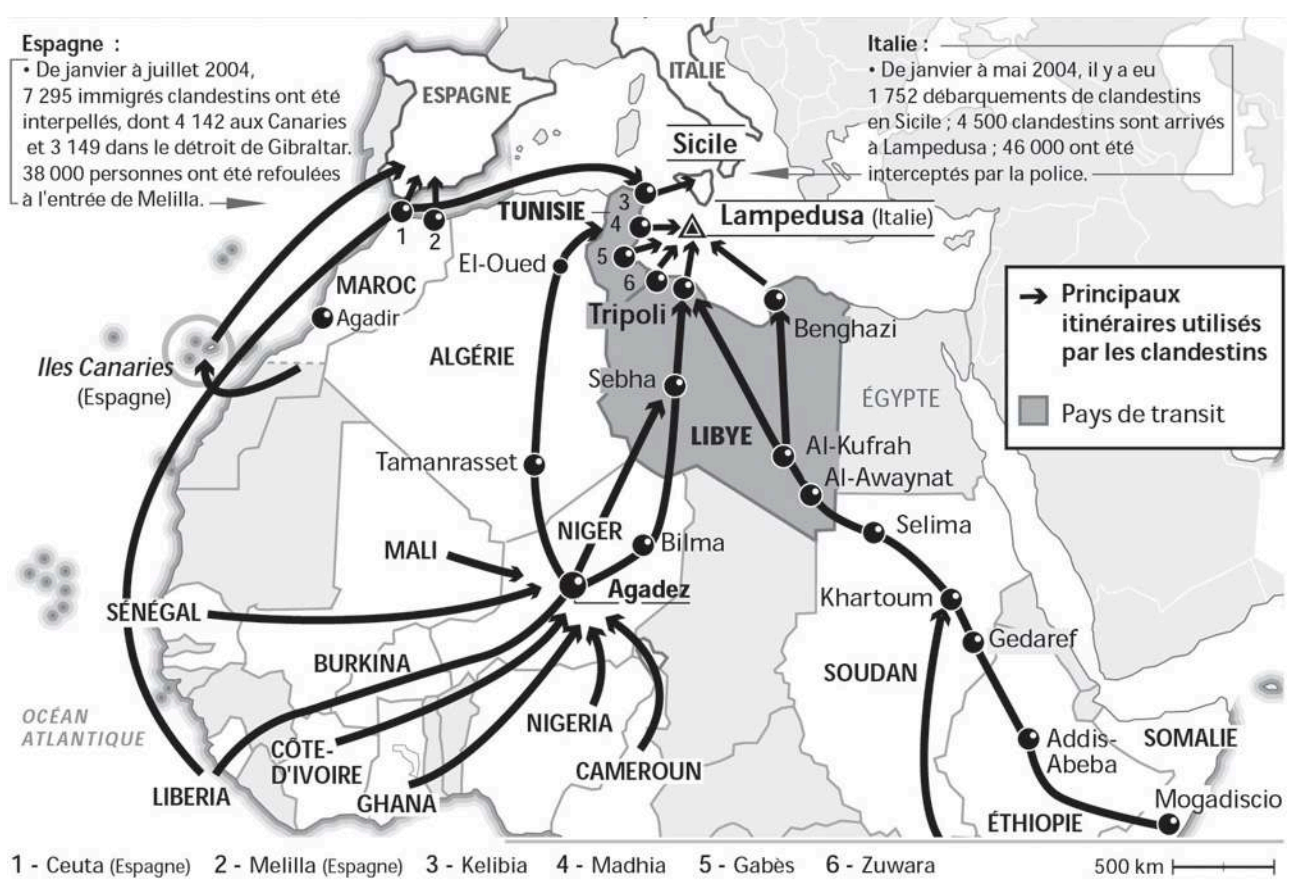

Source: http://www.lemonde.fr/international/infographie/2004/08/24/les-routes-africaines-de-limmigration-clandestine_628348_3210.html

Credit: Le Monde, 24 August 2004.

12 Certain maps published in scientific journals or the media tend to imply that population movements are statistically (very) significant in relation to the world population. This type of representation can be linked to the colours used: black or dark red do not necessarily convey the same message as cool colours, such as blue or green (Bertin J., 1967). Thus, the maps developed by "leading newspapers" such as Le Monde and The Guardian frequently over-emphasise the processes analysed (see Map 3). At a time when mapping software was less developed, some maps, such as those published in the journal REMI in 1992, left an impression a posteriori of mass arrivals, reinforced by the use - due to publication constraints - of the colour black. While for Simone Donnefort ${ }^{11}$, "the question did not arise during that period", Gildas Simon considers that:

"The aim was above all to show that there was a database of information behind this type of map. For example, those published in 1992 enabled some to highlight the significance of migration to Germany, in particular Turkish and Polish migration, compared to migration from North Africa to France; for others, they underlined that Irish migration to the United Kingdom was ongoing, etc. ${ }^{12}$... At that time there were very few of us producing this type of map, each of us tinkering around on his or her own, we worked by feeling our way and I imagine that maps are still produced like this ... We lacked perspective on these graphics which, in my opinion, were perceived differently. Nevertheless as time passes, I pay more attention to these representations. As Abel Bouillet, who taught me cartography, often used to remind me, although a map must be immediately intelligible, it is sometimes important not to base representation too much in the imagination of the readers." (Interview conducted on 4 February 2016)

Representing movements of refugees, migratory movements, with arrows may be described as a "cartographic temptation": the image they evoke can cause discomfort to both cartographers and readers by giving the impression, in some cases, that the 
arrows drawn on a map convey something other than that which the cartographers wished to portray. For example, maps representing flows of asylum seekers to Europe must be compared to the overall European population or the refugee population on the edge of conflict zones (nearly $84 \%$ of refugees worldwide in 2015). While flows may appear spectacular on certain maps, a comparison with other scales puts them into perspective. It should be recalled that between 2014 and 2015, the number of asylum seekers in Europe increased but the total number of these migrants represented under $0.3 \%$ of the population of the European Union in the same period. These representations can be linked to a "magnifying effect", as in some televised documentaries showing a close-up of the arrival of people at a border ${ }^{13}$. In this context, the cartographer, by enlarging the line with the arrow, reinforces the illusion of major influxes.

Maps representing flows of so-called "illegal" migration and whose main features are arrows without proportional value ${ }^{14}$, result in the minimisation of other international migration for which statistical data is available, even rendering it invisible. For example, only a proportion of illegal migration transiting through the Sahel region heads for the European continent; regional migration within Africa is much more significant (Lessault and Beauchemin, 2009). By concealing, intentionally or unintentionally, the diversity of population movement in the northern part of Africa, migration is too often reduced to the routes taken by criminal networks. It is not a question of denying the existence of these criminal economies, for which European migration policy bears some responsibility. The over-representation of connections between immigration and criminality is reinforced when maps show migration routes associated with the routes of trafficking in arms, drugs or other contraband. The map Trans-Sahara smuggling and trafficking routes (see Map 4) can be cited as an example, representing illicit trafficking to Libya, from Mali, Algeria, Chad, Sudan and Egypt. This map suggests erroneous interpretations in the sense that the responses to the fight against organised crime (arms, drugs) cannot be the same as those given to the migration of persons searching for protection or a better life. Such "cartographic absurdities" are often used in propaganda by extreme right xenophobic movements, opposing migration. For example, the Mouvement pour la remigration (Movement for Remigration) refers to Map 4, which is reproduced in one of their reports, to conclude that "the manufacture of refugees is a criminal enterprise like others ... Thus armed groups are always ["recruiting"] more and more refugees. These "migrants" unknowingly [become] criminal and terrorist bankers, financing equipment, men and arms. ... [According to this movement it is] essential to reaffirm the roots of refugees in their own territories in order not to cede ground to terrorists" ${ }^{15}$. 


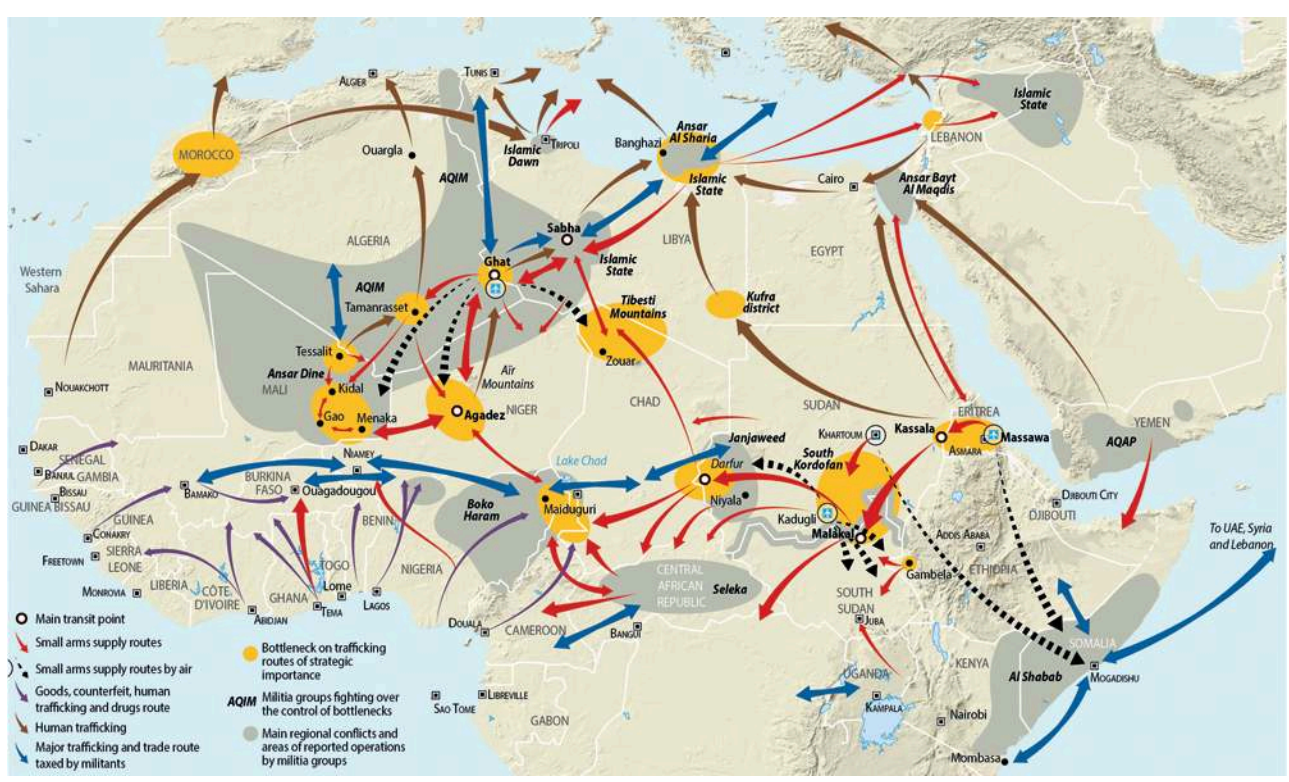

Source: Norwegian Center For Global Analysis, 2015.

Confronted with such remarks, which are false as well as being legally and politically unjustifiable, cartographers have to reflect on what they produce and the way they design maps. One issue is whether they should choose between the "arrow" - with or without proportional values - or the "route" in order to chart the migration environment more accurately, in relation to local and regional contexts.

\section{Awareness or Ignorance of (Geo)political Contexts}

Cartographic representations of migration flows often ignore the limits of the regional geopolitical situation that people face. For example, in the case of Syrian refugees fleeing war since 2011, the impossibility of going to Israel, the fears of the Sunni population about going to Iraq or Iran, difficulties in reaching the Gulf states and the South Caucasus are not indicated on the maps. Yet these various factors explain in part why the majority of refugees have settled in Jordan, Lebanon and Turkey, and why some then head to countries in Africa, Europe or even Latin America. Indeed, the majority of maps of migration flows give the impression of a territory where social problems, administrative and (geo)political obstacles and distance are not taken into account. "The designers of these maps (sometimes including ourselves) use numerous shortcuts, which they impose on the reader; they leave out essential but poorly documented issues concerning the hierarchy between flows or the significance of one of the agglomerations along the journey, or of the variability of the phenomenon, or its seasonal nature..." (Choplin A. and Pliez O., 2011).

It is difficult to show all this information on one map, since there is a risk the document becomes difficult to understand. Nevertheless, it is important to represent features which in part explain the environment in which people migrate. This type of cartography indicates various "rough patches" through which journeys pass. For example, looking at Map 5, entitled "Mobility of minors between sub-Saharan Africa and the EU", from the works of Nelly Robin (2014, p. 104), it can be observed that, in 
addition to employing different forms of transport (sea, land and air), young migrants take journeys with different characteristics at the various stages. At some points in time, people travel independently, at other times they resort to illicit means or are caught in trafficking networks. These diverse resources, sometimes chosen, sometimes endured, are found during circulation as well as while waiting in towns or border areas or during economic activity. The aim of this type of qualitative map is to comprehend the journeys making up migration flows "in their diversity and richness, to encompass them and unify them while taking account of the multiple forms, mechanisms and practices" (ibid.). Within these journeys, we also know that migrants can be subject to various types of legal status depending on the country in which they find themselves. They may also face controls or benefit from protection measures leading them to live highly heterogenous situations depending on the country (Migreurop, 2012, pp. 121-123), thus showing the "territoriality of legal risks" (Robin, 2014, p. 113).

Map 5: Mobility of Minors between Sub-Saharan Africa and the EU

Source: Robin Nelly (2013) Enquête « Mineurs migrants en transit ». Credit: Migrinter, 2013 - Pôle carto.

On most maps depicting migration flows, the authors adopt a satellite view which disregards the perspective of the people migrating. However, the representation of aggregated quantitative data does not necessarily conflict with the representation of qualitative and explanatory data. In this respect, Florence Boyer (2005, p. 432) has shown that Nigerian migrants undertaking circular migration between Bankilaré (Niger) and Abidjan (Côte d'Ivoire) via Niamey (Niger), characterised the stages of their migration journey differently: some stretches are "places for reconstructing social intimacy", others, familiar from past migration, are quite reassuring, while unfamiliar places represent danger (Map 6).

Map 6: Departing Migrants: Classifying Places along their Journey

Source: Boyer Florence (2001) Entretiens, observations, Ingui, route Niamey/Abidjan, Abidjan, mai-nov. 2001.

Credit: Migrinter, 2005

19 The author further states that "circular migration [and other forms of international mobility] are not geographically situated in the sense of being located on a map, since they involve multiple locations, as well as movement" (ibid.). In other words, it should not be forgotten that migration journeys are linked to local, regional and continental political contexts which act like springs in the migration dynamic. Showing the "scenery" and the "actors" within these "cartographic plays"16 (Rekacewicz, 2014), which take different forms at each stage of the process, underlines the significance of (geo)political contexts.

\section{Representing Migration Flows: An Ongoing Cartographic Challenge}

In 2015, 197 countries were recognised by the United Nations. A map representing all the flows between the various states would have to feature approximately 38,000 arrows to illustrate the links between each country and the other countries in the 
world ${ }^{17}$. Such a map would be illegible. In addition, movements are very complex. In migration nomenclature, many countries have several functions: Spain and Ukraine for example, are as much countries of departure as of transit and arrival. It is hard to establish typologies. Yet, ordering geographic spaces, or the way in which cartographers represent territory, is a condition for the conception of the world territory represented (Jacob, 1992). Choices must be made.

\section{Reconciliation between Data and Graphic Semiology}

The cartography of migration can be approached using different types of data: qualitative data (accounts of journeys), absolute, raw, quantitative data (stock variables and origin/destination matrices) and relative, processed, quantitative data (indicators). According to the rules of graphic semiology, conceptualised and formalised by Jacques Bertin, the various types of data determine specific modes of representation: value ranges to show relative data, proportional symbols to show stock data and arrows of proportional sizes to show quantitative flow data.

Cartographic productions on population migration are highly varied and heterogeneous, and appear to display two opposing trends.

Firstly, it can be observed that maps often contribute to the "immobilisation" of the processes described, by mainly using static data, in particular stock variables. This choice leads to the use of proportional symbols and to showing migration as a form of attachment (i.e. to countries of origin or arrival/or temporary stay, for a variable period of time). In this way, the representation of movement is avoided, by emphasising the result of a phenomenon, rather than the phenomenon itself (Bahoken, 2009). Such maps are easier to produce, since they resolve de facto the issue of the selection of relevant flows.

In contrast, the use of new technologies (graphic design tools, interactivity, animation, etc.) leads to the production of "dynamic" maps of migration. The process can be observed through the use of proportional arrows, a choice of semiology which is quite difficult to design and draw (overlaps, curvatures of arrows, choosing meaningful lines, bends, sizes proportional to other features on the map) but which can be useful in understanding some of the issues involved in movement and the importance of certain moves. However, maps may also make use of qualitative arrows based on scattered or incomplete information, which may lead them to convey erroneous cartographic messages.

\section{Scales and Temporalities}

One of the challenges presented by this type of map lies in the complexity of the available information and familiarising oneself with it. Indeed, migratory phenomena have a social dimension (type of population), a complex spatial dimension (origin, destination, stages, returns, etc.) and a strong temporal dimension (evolution of movements, waiting times, development of certain phenomena), which are particularly difficult for cartographers to express, forcing them to design maps with several levels of interpretation.

In order to combine these various aspects within a single cartographic document, it is necessary both to process data and to develop forms of representation. The facets of 
migratory processes appear differently depending on the scales of analysis and the levels of aggregation chosen. For example, statistical selections can contribute to reducing the "spaghetti" effect where there is significant overlap of flows. From a geographical point of view, changing the scale or level of aggregation makes it possible to go from a general picture to a more local scale, or even to abandon aggregated representations in order to tell individual stories.

The very topic of migration suggests a return to the mapping of routes and journeys. However, in contrast to the descriptive dimension of illustrations of travel and exploration routes, this type of cartography is intended to be analytical in that it attempts to represent the constraints experienced by those undertaking such journeys, which cannot be seen in the statistical data. Instead of presenting a global map, the intention is therefore to show all the places along a person's journey. Adopting this approach, representation of the temporal dimension makes it possible to capture the constraints which do not appear at the spatial level (waiting, wandering). However, relative technological complexity (animation, 3D) adds to methodological complexity and may represent an obstacle to cartographic production (cost, and processing time).

\section{New Technologies, New Forms of Mapping?}

"With a computer, we can make maps move" (Brunet, 1987). They can be animated and make interaction with the user possible. For the purpose of mapping migratory flows, this last point often represents a way of transferring responsibility for the selection of information from the cartographer to the map user. Numerous websites show maps on which it is possible to click on a specific country in order to see the incoming or outgoing population flows. These movements are shown in the form of proportional symbols $^{18}$, gradations of colour or lines of varying thickness ${ }^{19}$. Some representations based on infographics can be quite original ${ }^{20}$. When combined with temporal animation, such maps make it possible to chart the evolution of migration flows through time, country by country. The exhibition by Raymond Depardon and Paul Virilio, "Terre natale. Ailleurs commence ici", set up by American artists and architects Diller Scofidio, Renfro and Mark Hansen, Laura Kurgan and Ben Rubin, offers 360degree visualisations, in a 400 square-metre room, one showing the migration of refugees over the last five decades, another showing financial remittances transferred by migrants. They are probably among the most successful productions to date ${ }^{21}$.

However, when the authors of these dynamic mapping projects leave users to select information themselves (indicator, year, country), cartographers turn into developers and no longer play their role as thematic technicians since they abandon attempts to provide the keys to understanding the broad picture (or at least to convey their intention or worldview). With this type of application, the map is no longer a means of representing and revealing a specific outlook on the world, it is built by the developer of the application and by its user, who generates specific representations on request.

Yet these new dynamic mapping applications are not without political and ethical challenges: political intentions can sometimes be detected, as in the case of classic or conventional thematic cartography. On 26 October 2015, the Finnish news agency Lucify ${ }^{22}$ published an interactive and animated map (Map 7) depicting the flows of asylum seekers arriving in Europe between January 2012 and September 2015. The map was spotted by The Independent (27 October 2015) and published in the French press 
(Slate on 29 October 2015, l'Observateur on 30 October 2015) and spread through the Internet like wildfire. Firstly, this Eurocentric map only represented flows towards "European" countries. Refugees received in other countries (such as Jordan, Lebanon and Turkey, which receive the majority of them) are not represented. Secondly, the choice of graphics used to represent the information are indicative of the intentions of authors. On this animated map, the movements of asylum seekers are represented by short lines moving from the countries of departure towards the countries of arrival. Contrary to first impressions, this map does not show individual journeys. It does not tell the stories of migrants. Far from the winding realities of real migratory journeys, each line (which represents 25 or 50 people) follows a straight path like a missile launched towards Europe. Ultimately, this animated graphic semiology stages a quasimilitary invasion, with European countries under attack and invaded by foreigners. It is difficult to know whether the invasion rhetoric used in this map has been consciously and deliberately chosen. However, it is clear that this agency, which is not specialised in cartography, intended to show the "scale of the crisis" of refugees. This map is probably the result of clumsiness (in the selection of data) and intent to convey a preconception (the mass arrival of exiles in Europe) in graphic form.

Map 7: The Flow towards Europe, Lucify, 26 October 2015

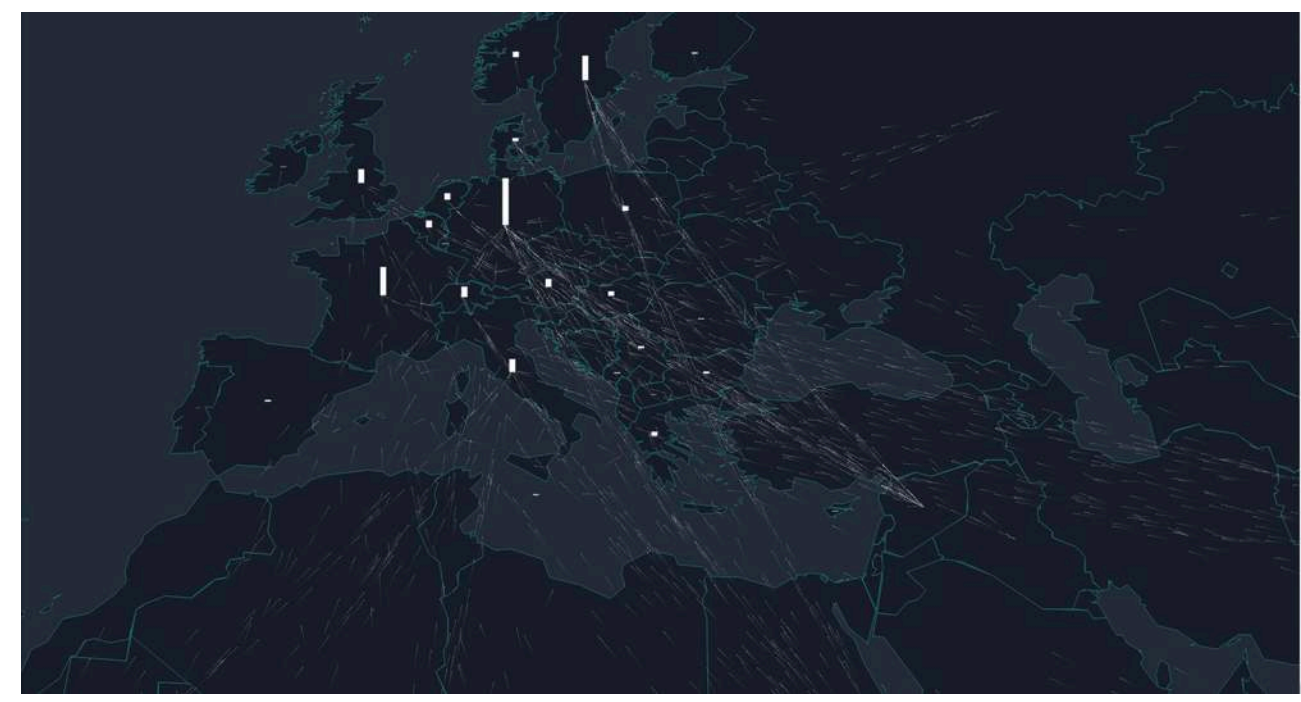

Source: http://www.lucify.com/the-flow-towards-europe/

Credit: Ville Saarinen and Juho Ojala, 2015; MIT License (MIT) - https://github.com/lucified/lucifyrefugees

Beyond graphic semiology, a map is the result of a technical and intellectual process which consists in converting known or lesser known concrete data, into an abstract representation (Lacoste Y., 1976). Yet, this graphic abstraction replaces the richness of the plurality of stories experienced with a holistic representation which attempts to provide a view of the world. In practice, geographic maps, in their construction and semiology often fail to reflect reality. They plot and schematise the geography of spatial phenomena, but they do not tell the real story. Do maps showing the deaths of migrants at the borders ${ }^{23}$ document the human tragedies which relentlessly unfold? And what does "documenting" these tragedies mean in the field of cartography and more broadly in that of science? If graphic semiology used in scientific cartography has 
its limits, what about the artistic approach? Can art describe geographic space differently?

\section{The Cartography of Migration at the Intersection of Art, Science, Politics and Activism}

Out of all the maps representing international migration, certain productions stand out from conventional representations, in textbooks, academic books or atlases. Such maps challenge the rules governing institutionalised base maps and graphic semiology. They invent new languages and upset standard references for the production and interpretation of maps. These individual or collective productions are designed by cartographers, artists, activists and people in exile. While they form a highly heterogeneous corpus, they all reflect, to varying degrees, a position which may be characterised as "critical", "experimental" (Crampton, Krygier, 2005; Gintrac, 2012), "interdisciplinary" or "participatory" (Mitchell, 1995), each of these terms refers to distinct epistemological perspectives. By questioning standards of representation, these maps seek to challenge the positivist project of knowledge neutrality. Without claiming to be exhaustive, in this third part of the article we will explore the myriad of critical maps of migration, attempting to discern at least two main trends: maps which allow us to see, using the metaphor of uncovering, that is, mechanisms designed to monitor and control migration in order to denounce them; and maps which document individual and collective migratory journeys and experiences. Clearly these two categories do not reflect the richness of the various perspectives. This open typology, requiring further exploration and debate, is conceived as an invitation to pursue the reflection on methods used to depict migratory processes.

\section{Maps “Uncovering” Migration Control Mechanisms}

The following productions take a different approach to that adopted in maps of migration flows: they do not represent movement, rather they seek to show everything that impedes, restricts, prolongs or redirects it. These maps, by exposing control mechanisms, serve as the basis of scientific and political arguments, and sometimes even as legal evidence.

The Atlas of Migration in Europe, subtitled A critical geography of migration policies (Migreurop, 2013) ${ }^{24}$ produced by the scientific and activist collective Migreurop, falls within this "topic of denunciation" (Boltanski, 2007, p. 113). Using base maps and drawing on conventional graphic semiology, the critical aspect here consists of the data represented ${ }^{25}$. Although many maps in the Atlas use data compiled by bodies responsible for recording migration for control purposes ${ }^{26}$, this data is partly subverted to show the adverse, if not deadly, consequences of control mechanisms.

Other productions criticise migration policies by representing data which make it possible to understand their operations and impact, but also by disrupting cartographic conventions.

In his Carnet (Néo)cartographique, Nicolas Lambert, one of the authors of the Atlas, presents "cartographic metaphors" 27 created with Olivier Clochard (Clochard and Lambert, 2015). On the basis of statistics on migrant mortality at the borders of the 
European Union and press illustrations, three maps explore original depictions of borders. The combination of statistical and media sources used to create these maps gives rise to works which call into question migratory processes (in relation to the rate of mortality during migration) as well as the media coverage of such processes.

The Critical Cartography of Gibraltar (2004), created by Hackitectura ${ }^{28}$, a collective of artists, scientists and activists, based in Spain, constitutes a "tactical map". A referential map based on the Gibraltar Strait shows data on the locations and operation of the European Union's monitoring mechanisms. The representation of the land in yellow, the sea in black and the proliferation of symbols of monitoring mechanisms support a critical view of the hyper-securitisation and militarisation of this area.

Map 8: Extract from the map created by Hackitectura

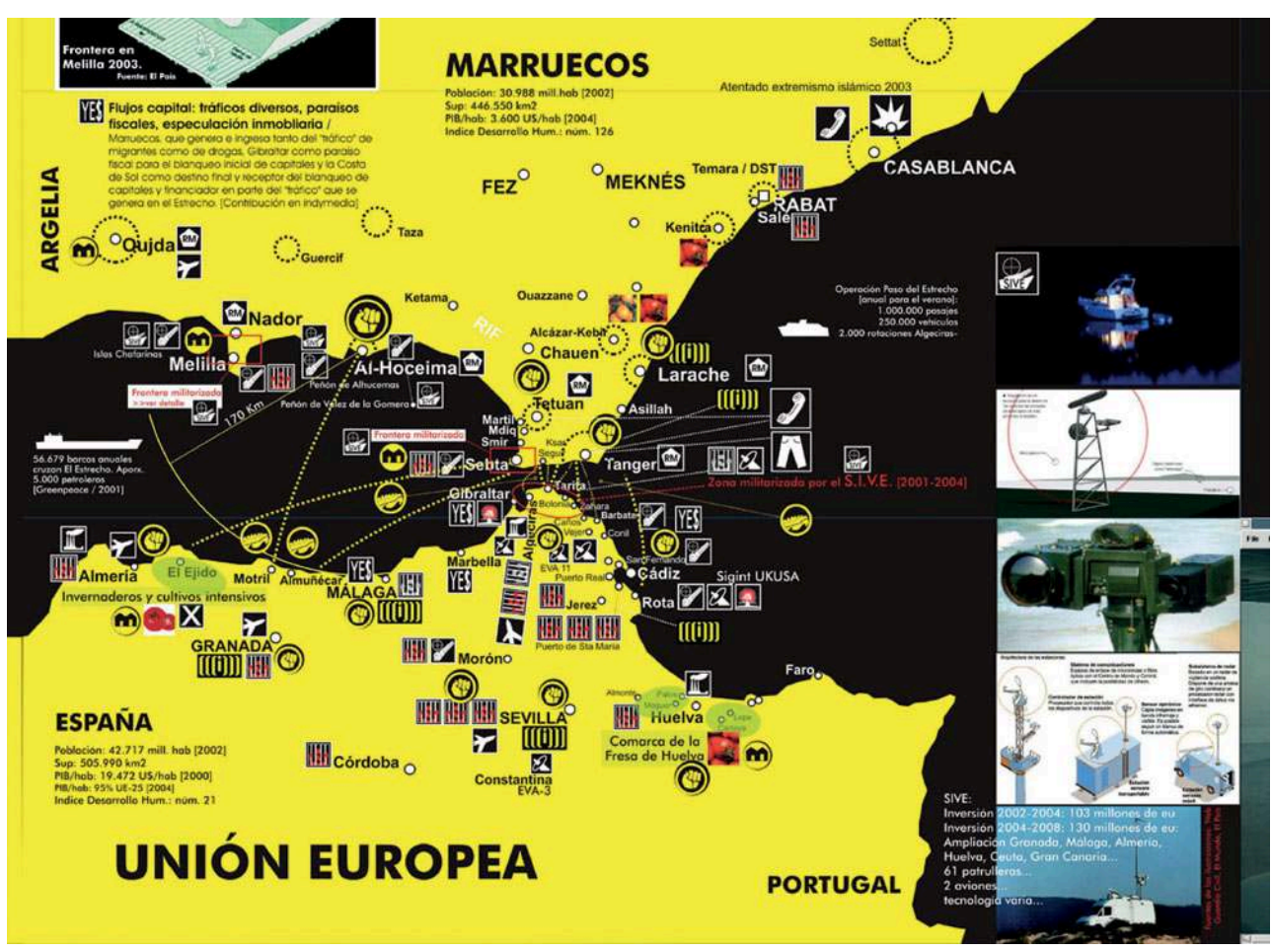

Source: http://x.hackitectura.net

Credit: Hackitectura.net, 2017

Using an approach in which the topographic framework is absent, Migmap, an artistic creation project produced by $\mathrm{k} 3000$, a platform for the conservation and exhibition of artwork established in Germany, is a creation that includes four visual components displaying European migratory policies ${ }^{29}$. Using dynamic and interactive depictions, the maps show political statements, networks of actors, and significant places and practices in the context of migration policies, as well as the process of Europeanisation from which they originate. 


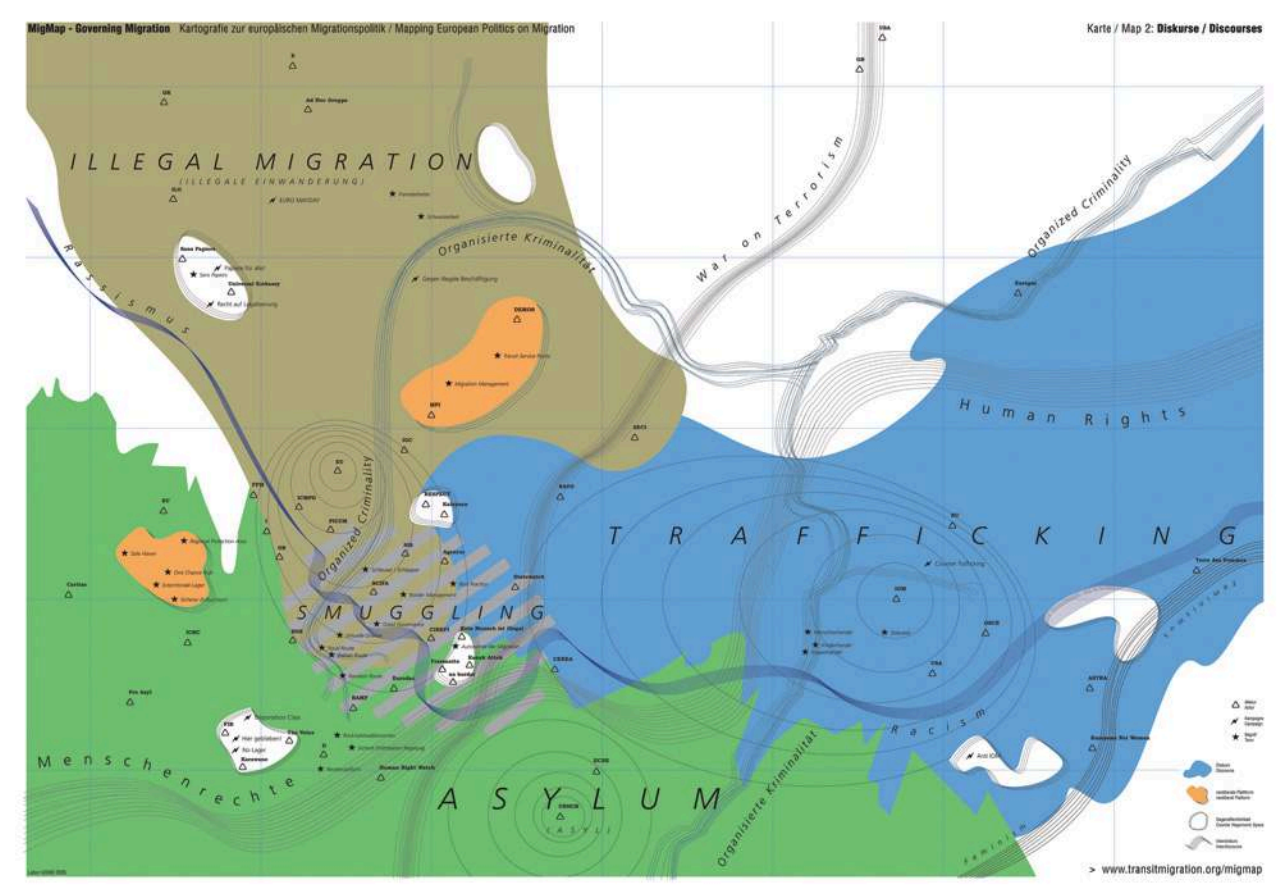

Source: http://www.transitmigration.org/migmap/home_map2.html Credit: Labor k3000, 2004. participative and dynamic mapping of Close the Camps, created by Migreurop in 2013, which seeks to expose the Europe of "camps" by "mobilis[ing] all those who oppose migrant detention and removal measures with the aim of protecting migrants' fundamental rights". Elements drawn from the experiences of individuals who have been held in migrant camps are juxtaposed with a project aimed at identifying camps. Another example is the series of maps produced by Philippe Rekacewicz, and published in Le Monde Diplomatique and on the blog Visionscarto.net. Drawn by hand, these maps break with the illusion of "objective maps" without authors and reclaim cartographers' sensitivity. The singularity of this cartographic gesture, based on sketches, humanises the map and, beyond the map, the subject it represents. 
For example, Map 10 on the "African big wheel", drawn by hand, demonstrating both scientific and artistic ambition, situates migration issues within a system of geopolitical and economic causalities, which exist on the African continent and between Africa and other continents. The map depicts a complex system of exchange in which the African continent is literally "entangled". It describes perpetual movement between Africa and various partners, which could be represented only very imperfectly by arrows. The wheel, a continuous form of representation, symbolises permanence and continuity in the context of a profoundly unequal exchange: "Africa saves Europe, which impoverishes Africa, which feeds Europe, which enslaves Africa, which pays Europe, which continues to rob Africa ...". This circular symbology can be considered as an alternative form of representation to the arrow.

Map 10: The "African big wheel"

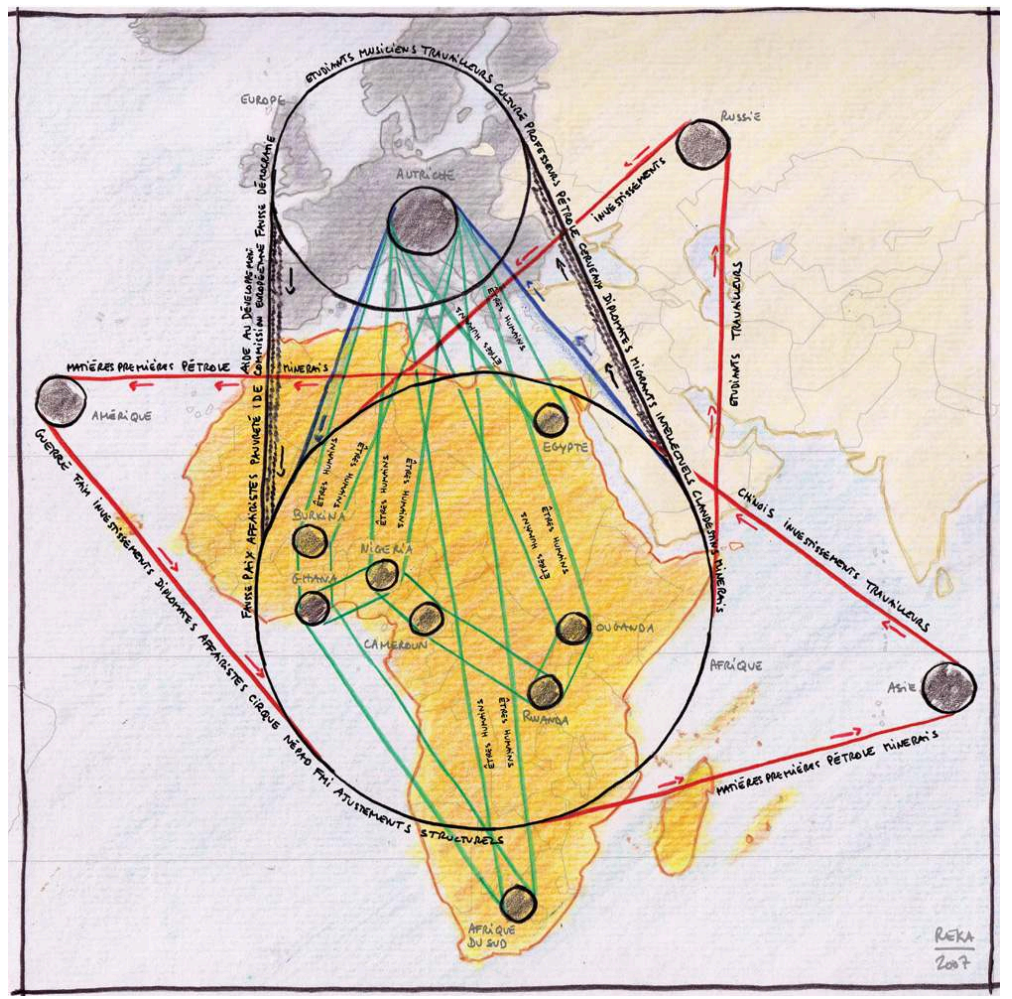

Credit: P. Rekacewicz, 2007

The maps presented in the following section, rather than showing systems of causality and control mechanisms, more specifically relate individual and collective experiences, by suggesting the viewpoint of those who move.

\section{Critical Maps of Migration Experiences}

The maps presented below focus on the obstacles and opportunities, the constraints and resources, the realities and fantasies involved in the journeys made.

The hand-drawn maps of individual migration journeys produced in the exhibition "Moving Beyond Borders" 30 are an example of this approach. Presented as a duo with digital maps on control mechanisms, each hand-drawn map aims to represent their impact on individual routes and experiences. The map drawn by Lucie Bacon entitled 
"Five years to reach Hamburg from Kabul" illustrates this. It was created on the basis of an interview by Bénédicte Michalon, researcher and member of Migreurop, of an Afghan citizen she met in Romania., and. The map conveys the burden of detention, temporalities and areas covered, voluntary and forced mobility, and the many different experiences of deprivation of liberty.

Map 11: Extract from one of the maps "Five years to reach Hamburg from Kabul"

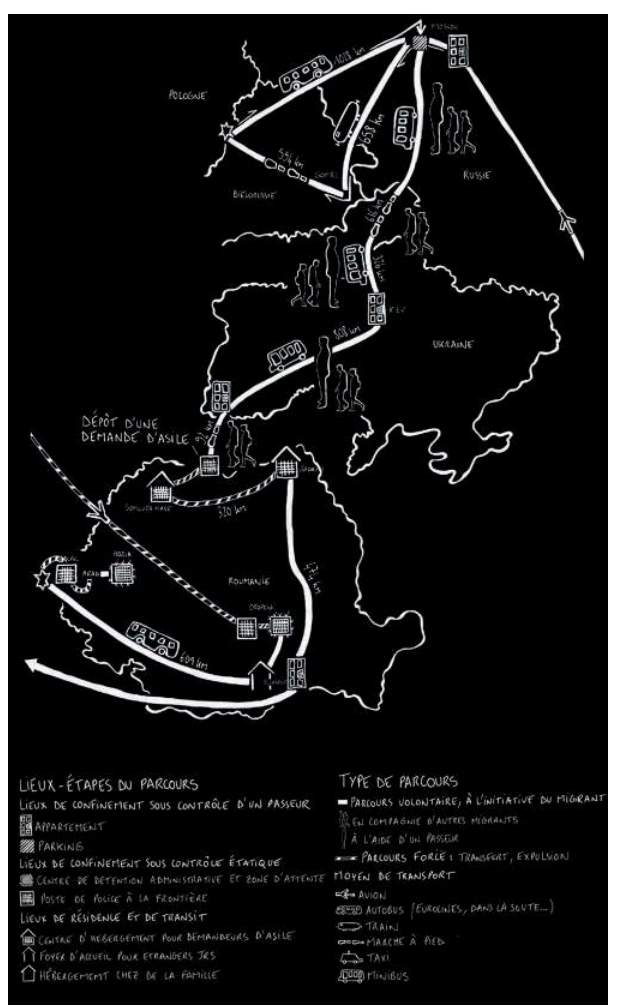

Source: Michalon Bénédicte (2010) Entretien réalisé à Bucarest. Credit: L. Bacon, 2015.

Taking an approach aimed at visualising narrative and discursive data, the cartographic artwork "H-OUT-Guide de l'immigration", created in 2010 by the Algerian graphic designer and illustrator Zineddine Bessaï, was designed as a guidebook based on maps for the use of the harragas ${ }^{31}$. The map shows the Mediterranean and its two shores, with many symbols representing control mechanisms, but also depicts accounts heard on the shores of the Maghreb. The toponyms are transliterations from the Arabic and use vocabulary connected to the harragas: for example, Europe is translated as "Oropa" and the Mediterranean Sea as "la mort méditerranée" (the Mediterranean death).

"The Mapping Journey Project", an installation created between 2008 and 2011 by the French-Moroccan artist Bouchra Khalili, also forms part of the process of narrative mapping. Composed of eight short films (The Mapping Journey) and eight screen prints (The Constellations), this installation displays audiovisual accounts of individual migration journeys. Each video is a static shot in which a hand moves to trace a journey over a conventional map base. The image is accompanied by the voice of the person drawing, who tells a story. The screen prints (based on eight accounts, made in five different countries and six different cities) map journeys in the form of constellations 
of white stars on a solid blue backdrop, thereby calling into question conventional topographic references.

Map 12: The Constellations (Figure 8 from the series The Constellations, 8 screen prints. $60 \times 40 \mathrm{~cm}$, 2011)

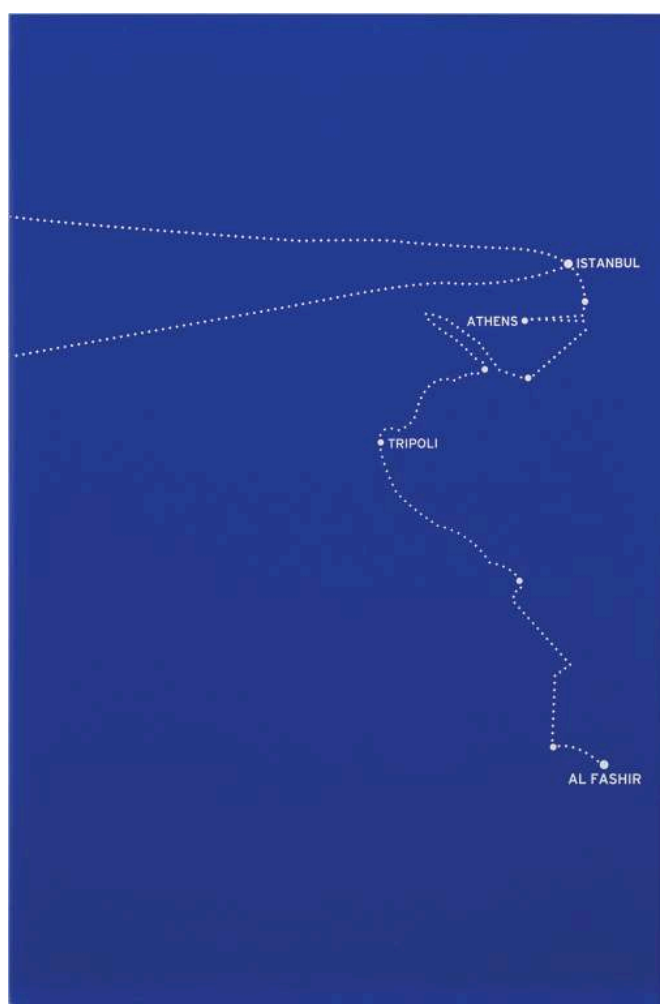

Source: The Opposite of The Voice-Over, solo exhibition, Färgfabriken Konsthall, Stockholm, 2016. and eight persons who crossed the border between Mexico and the United States. This work approaches the map from a "more-than-representational" perspective. In other words, attention is focused not only on what the map represents but also on the map itself as an object transported during travels. From 2003 to 2006, the artist gave forty maps representing North America to twenty persons who were preparing to cross the Mexican northern border into the United States. Each of these persons received two maps: the first to be kept and the second to be sent to the artist on arrival. This installation brings together the eight maps which Pedro Lasch received. Crumpled, folded, discoloured, they bear the marks of the crossing. Each of them is accompanied by a label indicating the name of the person who is the co-author of the map, together with some elements relating to his/her experience.

Finally, the art installation "Cartographies traverses / Crossing Maps" was produced through a shared creative process. This installation was created in 2013 by researchers, artists and twelve asylum seekers and refugees living in Grenoble ${ }^{32}$. The co-authors came together in a workshop where they produced a collective key using significant words from experiences of migration. The words were symbolised by stickers in 
different shapes and colours. Based on this work, which was intended to overcome the fragmentation of individual statements, each participant drew several maps using the collective key. Some also moulded their map in clay or drew and embroidered it on large white tablecloths, at the invitation of visual artist Marie Moreau. As well as exploring methods used to depict experiences of migration, this work constitutes research on forms of relationships between artists, researchers and persons struggling for their rights.

Map 13: The World is Stopping Us

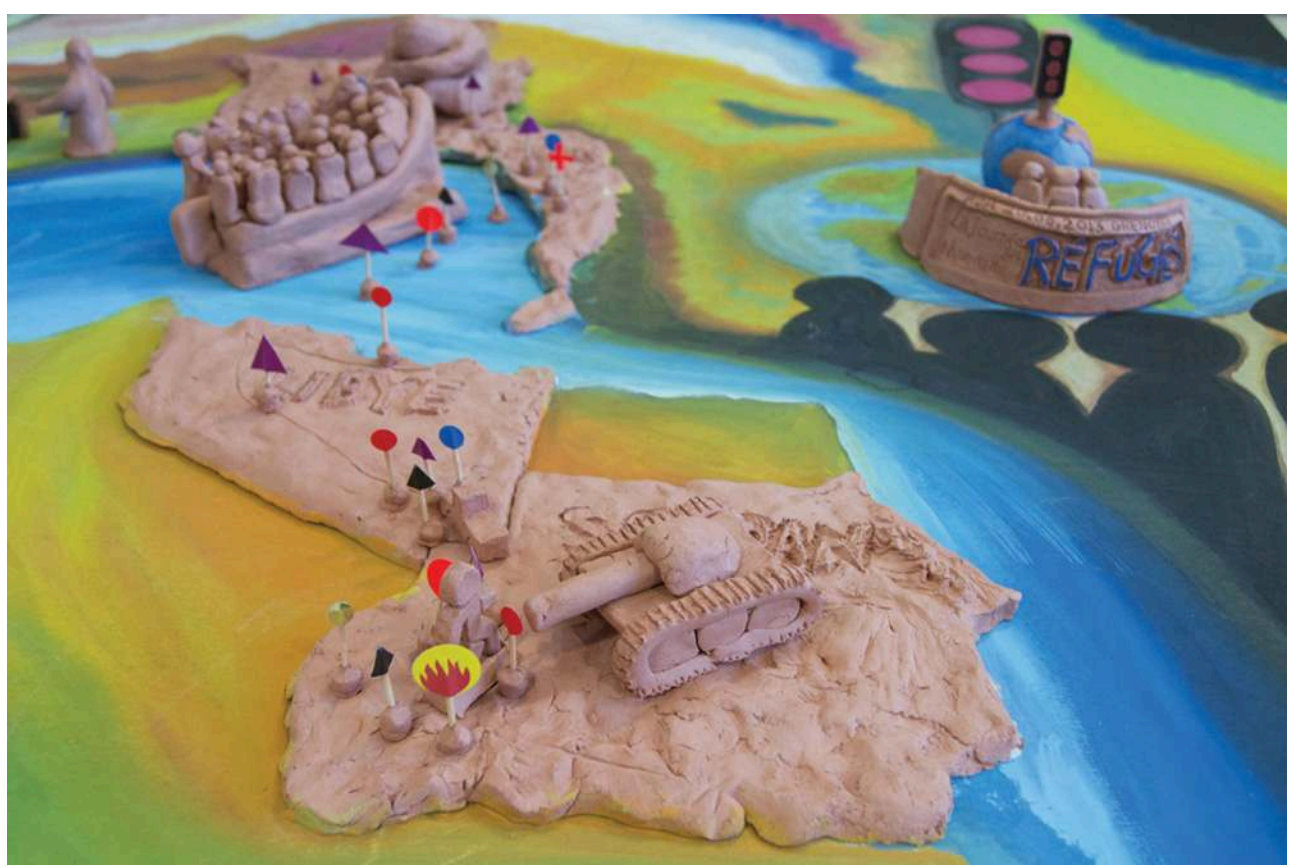

Source: Gladeema Nasruddin (2013) Ateliers de cartographie à Grenoble. Credit: Mabeye Deme, 2013.

\section{Conclusion}

51 In the same way that research on international migration developed new theoretical and conceptual frameworks to think about the changes to mobility and its increasing complexity, such international dynamics seem to call into question the foundations of cartography. Migration not only requires us to take another look at territory and borders in their conventional form, but also leads to the emergence of other types of representation of space, movement and the connected political challenges.

Some of the maps we have presented, notably in the last part of this article, share the feature of combining (and assuming) artistic, political, scientific and activist intentions. They may be defined as "far-removed from academic customs and practices", positioning themselves "against uniform thinking" (Lambert, 2013).

However, these maps should not be viewed simply as "counter-maps": rather than setting them against maps which comply with a standardised system of representation (arrows, for example), they should be considered as complementary. Such maps, which adopt positions of uncovering and denunciation, and engage in processes of individualisation of cartographic gestures and depictions, aim to change our 
impressions of migration, which are largely constructed on the basis of omnipresent and recurring images, particularly cartographic representations.

\section{BIBLIOGRAPHY}

Amilhat-Szary Anne-Laure, Fischer Fabien, Houbey Lauriane, Mekdjian Sarah, Moreau Marie et douze habitant.e.s grenoblois.e.s (2013) Cartographies traverses/Crossing Maps, [en ligne]. URL : http://www.antiatlas.net/blog/2013/09/20/crossing-maps-cartographies-traverses/

Avelot René (1905) Ethnographie et migrations au Gabon et au Congo Français, 1/4 000 000, [en ligne]. URL : http://gallica.bnf.fr/ark:/12148/btv1b8444725n/f1.item.r=congo.langEN

Bahoken Françoise (2013) Sur la première carte des flux réalisée avec des flèches (Ravenstein, 1885), Confins (revue franco-brésilienne de géographie/revista franco-brasilera de geografia), 17, [en ligne]. URL : http://confins.revues.org/8187

Bahoken Françoise (2012) Contribution du raisonnement logique à la cartographie des flux, in Rolland Billen, Marc Binard, Pierre Hallot et Jean-Paul Donnay, Actes de la Conférence internationale de Géomatique et Analyse Spatiale, Université de Liège (6 au 9 novembre 2012), pp. 13-29, [en ligne]. URL : https://orbi.ulg.ac.be/bitstream/2268/133126/1/PROCEEDINGS_A4.pdf

Bahoken Françoise (2011) Représentation graphique des matrices. Graphe et/ou carte des flux ?, 13 p. [en ligne]. URL : https://halshs.archives-ouvertes.fr/halshs-00641733/document

Bahoken Françoise (2009a) Les documents cartographiques en ligne sur les migrations internationales, e-migrinter, 3, pp. 37-52, [en ligne]. URL : http://migrinter.labo.univ-poitiers.fr/ wp-content/uploads/sites/150/2016/05/emigrinter2009_03_tout.pdf

Bahoken Françoise (2009b) Atlas sur les migrations internationales, e-migrinter, 3, pp. 53-57, [en ligne]. URL : http://migrinter.labo.univ-poitiers.fr/wp-content/uploads/sites/150/2016/05/ emigrinter2009_03_tout.pdf

Béguin Michèle et Pumain Denise (2007 [réédition]) La représentation des données géographiques : statistique et cartographie, Paris, Armand Colin, $192 \mathrm{p}$.

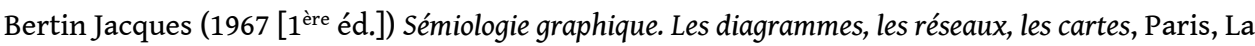
Haye, Mouton, Gauthier-Villars, $452 \mathrm{p}$

Bessaï Zineddine (2010) H-OUT-Guide de l'immigration, [en ligne]. URL : http://

zineddinebessai.com/portfolio/h-out/

Boltanski Luc (2007) La souffrance à distance, Paris, Folio Essais, 528 p.

Boyer Florence (2005) Être migrant et Touareg de Bankilaré (Niger) à Abidjan (Côte d'Ivoire) : des parcours fixes, une spatialité nomade, Thèse en géographie, Université de Poitiers, 578 p.

Brunet Roger (1987) La carte mode d'emploi, Paris, Fayard, 270 p.

Choplin Armelle et Pliez Olivier (2011) De la difficulté de cartographier l'espace saharo-sahélien, M@ppemonde, 103, [en ligne]. URL : http://mappemonde.mgm.fr/num31/intro/intro2.html 
Clochard Olivier et Honoré Thomas (2015) Représenter des flux migratoires : un défi cartographique, Carto, 31, pp. 54-56.

Clochard Olivier and Lambert Nicolas (2015) Mobile and Fatal: The EU Borders, in Anne-Laure Amilhat Szary and Frédéric Giraut Eds, Borderities and the Politics of Contempory Mobile Borders, New-York, Palgrave McMillan, pp. 119-137.

Cosgrove Denis (2001) Apollo's Eye: A Cartographic Genealogy of the Earth in the Western Imagination, Baltimore, The Johns Hopkins University Press, 352 p.

Crampton Jeremy W. (2009) Cartography: Performative, Participatory, Political, Progress in Human Geography, 33 (6), pp. 840-848.

Crampton Jeremy W. and Krygier John (2005) An introduction to Critical Cartography, ACME-An International E-Journal for Critical Geographies, 4 (1), pp. 11-33, [online]. URL: http://acmejournal.org/index.php/acme/article/view/723

Cvijić Jovan (1918) Courants métanostasiques dans le peuplement des pays serbes du XVe siècle à nos jours, Paris, Armand Colin, [en ligne]. URL : http://gallica.bnf.fr/ark:/12148/btv1b53060979d.r=

Delage Cécile et Miellet Philippe (2001) Représentation cartographique : guide méthodologique, Paris Certu, Gip Aten, 87 p.

Forensic Architecture (2011) The Let-to-Die Boat, [online]. URL: http://www.forensicarchitecture.org/case/left-die-boat/

Gintrac Cécile (2012) Géographie critique, géographie radicale : Comment nommer la géographie engagée ?, Carnets de géographes, 4, [en ligne]. URL : http://www.carnetsdegeographes.org/ carnets_recherches/rech_04_04_Gintrac.php

Gould Peter et Bailly Antoine (1995) Le pouvoir des cartes, Brian Harley et la cartographie, Paris, Economica, $120 \mathrm{p}$.

Hackitectura (2004) Cartografía crítica del estrecho de Gibraltar, [en línea]. URL: http:// dunadigital.com/blog/2004/07/11/cartografia-critica-del-estrecho-de-gibraltar-fadaiat-2004/

Heller Charles et Pezzani Lorenzo (2014) Traces liquides : enquête sur la mort de migrants dans la zone-frontière maritime de l'Union européenne, Revue Européenne des Migrations Internationales, 30 (3), pp. 71-107, [en ligne]. URL : http://remi.revues.org/7106

Jacob Christian (1992) L'Empire des cartes: Approche théorique de la cartographie à travers l'histoire, Paris, Albin Michel, 532 p.

Kaddouri Lahouri (2008) Réflexion sur la sémiologie graphique animée des flux, Mappemonde, 89, [en ligne]. URL : http://mappemonde.mgm.fr/num17/articles/art08104.html

Khalili Bouchra (2011) The Mapping Journey Project, [online]. URL: http:// www.bouchrakhalili.com/the-mapping-journey-project/

Lacoste Yves (1976) La géographie, ça sert, d'abord, à faire la guerre, Paris, Maspéro, 248 p.

Lambert Nicolas (2013) Cartographie radicale, Carnet Neocartographique, [en ligne]. URL : http:// neocarto.hypotheses.org/15

Lambert Nicolas (depuis 2010) Carnet Néocartographique, [en ligne]. URL : http:// neocarto.hypotheses.org/

Lasch Pedro (2006) Latino/a, [online]. URL: http://www.pedrolasch.com/latinoaamerica.html 
Lessault David et Beauchemin Cris (2009) Ni invasion, ni exode, Revue Européenne des Migrations Internationales, 25 (1), [en ligne]. URL : http://remi.revues.org/4889

Lévy Jacques, Poncet Patrick et Tricoire Emmanuelle (2004) La carte, enjeu contemporain, La documentation photographique, 8036, $63 \mathrm{p}$.

Liagre Romain (2008) De la difficulté de cartographier les itinéraires migratoires clandestins, Espace populations sociétés, 3, pp. 453-461, [en ligne]. URL : http://eps.revues.org/3520

Mekdjian Sarah (2015) Mapping Mobile Borders. Critical cartographies of borders based on migration experiences, in Anne-Laure Amilhat Szary and Frédéric Giraut Eds., Borderities and the Politics of Contemporary Mobile Borders, New-York, Palgrave McMillan, pp. 204-224.

Mekdjian Sarah, Amilhat-Szary Anne-Laure, Moreau Marie, Nasruddin Gladeema, Deme Mabeye, Houbey Auriane et Guillemin Coralie (2014) Figurer les entre-deux migratoires : Pratiques cartographiques expérimentales entre chercheurs, artistes et voyageurs, Carnets de géographes, 7 , [en ligne]. URL : http://www.carnetsdegeographes.org/carnets_terrain/ terrain_07_01_Mekdjian.php

Migreurop (depuis 2013) Closethecamps, [en ligne]. URL : http://closethecamps.org/

Migreurop (2012) Atlas des migrants en Europe. Géographie critique des politiques migratoires, Paris, Armand Colin, $144 \mathrm{p}$.

Migreurop et Étrange Miroir (2015) Moving Beyond Borders, [en ligne]. URL : http:// www.migreurop.org/article2601.html

Mitchell William John Thomas (1995) Interdisciplinarity and Visual Culture, Art Bulletin, 77 (4), pp. 540-544.

Poulain Michel (1992) Un projet d'harmonisation des statistiques de migration internationale au sein de la Communauté Européenne, Revue Européenne des Migrations Internationales, 8 (1), pp. 163-186.

Rekacewicz Philippe (2014) Entre imaginaire et réalité : l'intention cartographique, Revue 303, 133, pp. 8-15.

Rekacewicz Philippe (2013) Cartographie radicale, Le Monde diplomatique, février, p. 15 [en ligne]. URL : http://www.monde-diplomatique.fr/2013/02/REKACEWICZ/48734

Rekacewicz Philippe (2006) La cartographie, entre science, art et manipulation, Le Monde diplomatique, février, pp. 14-15, [en ligne]. URL : http://www.monde-diplomatique.fr/2006/02/ REKACEWICZ/13169

Rekacewicz Philippe et Rivière Philippe (depuis 2014) Visionscarto, [en ligne]. URL : http:// visionscarto.net/

Robin Nelly (2014) Migrations, observatoire et droit. Complexité du système migratoire ouest-africain. Migrants et normes juridiques, Habilitation à diriger des recherches, vol. 1, Université de Poitiers, $143 \mathrm{p}$.

Robinson Arthur H. (1955) The 1837 maps of Henry Drury Harness, The Geographic Journal, 121 (4), pp. 440-450.

Schrader Franz et Gallouédec Louis (1923) Atlas classique de géographie ancienne et moderne, Paris, Hachette.

Simon Gildas (2009) Migrations, la spatialisation du regard, Revue Européenne des Migrations Internationales, 22 (2), pp. 9-21, [en ligne]. URL : http://remi.revues.org/2815 
Simon Gildas (2008) La planète migratoire dans la mondialisation, Paris, Armand Colin, 255 p.

Simon Gildas (1992) Une Europe Communautaire de moins en moins mobile ?, Revue Européenne des Migrations Internationales, 8 (1), pp. 67-87, [en ligne]. URL : http://www.persee.fr/doc/ remi_0765-0752_1992_hos_8_1_1034

Transit Migration (2005) Migmap, [online]. URL: http://www.transitmigration.org/migmap/ Wood Michael (2004) La cartographie est éternelle, Géomatique Expert, 34, pp. 19-26, [en ligne]. URL : http://www.geomag.fr/rev/pdf/34_34.pdf

\section{NOTES}

1. See, for example, the map "From Kabul to Calais, Khan's route", designed and produced by Thomas Honoré and Emmanuelle Hélio (Migreurop, 2012).

2. Sources of the many statistical databases used to produce maps of migration flows, on various scales, include Eurostat, the Office of the United Nations High Commissioner for Refugees (UNHCR), the Organisation for Economic Cooperation and Development (OECD), the French Institute for Demographic Studies (INED), etc.

3. Unlike traditional journalism, which does not reveal or rarely reveals its sources, data journalism indicates the data used and makes them accessible through visualisation tools (e.g. OWNI, http://owni.fr/tag/data-journalisme.1.html; The Migrants Files, http:// www.themigrantsfiles.com)

4. http://closethecamps.org/

5. For example, the map of "Deaths at the borders", conceived in 2002 by Olivier Clochard, would have been impossible to create without the work of members of the NGO UNITED in Amsterdam and their network, who were the first to try to document the deaths of migrants during the 1990s. They were subsequently supplemented by personal initiatives such as that of the journalist Gabriele Del Grande (see her website http://fortresseurope.blogspot.fr) and more recently by institutions such as the International Organisation for Migration (IOM) and the Office of the United Nations Commissioner for Refugees (UNHCR). Since 2013, the open and participatory project, The Migrant Files (http://www.themigrantsfiles.com/) compiles and cross-references statistics recorded in various databases since 2000. These "data producers", with regular updates, are also very important contributors to the "creation" of maps. The mapping work of nongovernmental actors and individuals is highly vulnerable and can come to an end overnight due to a lack of human or financial resources, depriving us of often crucial information, which is unavailable elsewhere. It is to be noted that the first version of the map "Deaths at the borders of the European Union" appeared in the journal Les cahiers d'outre-mer (Clochard, 2003). It was then revised by Philippe Rekacewicz and published in 2004 in the newspaper, Le Monde diplomatique. Since then it has been updated and further developed several times.

6. A "first group of arrows seems... to illustrate local mobility across a short distance within countries... A second group seems to represent internal flows, characterised by the absence of a boundary crossing. A third group of arrows is formed by inter-state flows (between Ireland and England) suggesting longer distance mobility" (Bahoken, 2013, p. 6).

7. The year of publication of the map is not specified. In view of the lifetime of the publisher Iliine Alekseï Alekseevitch (1832-1889), it would appear that the document was produced during the second half of the $19^{\text {th }}$ century, perhaps even during the same period as the Ravenstein map. See http://gallica.bnf.fr/ark:/12148/btv1b84451358.r=migration

8. " 60 million candidates set off for the Americas between 1820 and 1914 from countries of origin, the most spectacular case being Ireland, which saw more than a third of its population leave: 3 
million departures between 1845 and 1870. As for host countries, the annual rate of entry into the United States went from 300,000 in 1850 to more than 1 million from 1900, and reached 1.4 million on the eve of the war" (Simon, 2008, p. 32).

9. See also the works of Matthew Sankey on the Wikipedia page about him.

10. This research, which requires further development, draws on document searches at the Bibliothèque nationale de France (BNF), in particular using the Gallica website (http:// gallica.bnf.fr), the Geography Department at the University of Poitiers. and the work of the six authors of this article.

11. After graduating from the École supérieure de cartographie géographique in 1967, she was a cartographer at Migrinter from its creation until the 1990s. She was very close to Michèle Béguin who passed away on 12 March 2014.

12. See Simon, 1992.

13. See for example, La nuit des réfugiés with six documentaries broadcast on Arte on 6 October 2015.

14. By definition, such migration cannot be quantified.

15. Mouvement pour la Remigration (2015) Rapport choc: pourquoi faut-il cesser de recevoir des migrants? http://www.mouvementpourlaremigration.fr/blog/ We do not share the opinions expressed by the authors of this article.

16. Philippe Rekacewicz, Cartes en colère, exhibition of maps in the Maison des métallos, Paris, October 2012.

17. i.e. $(197 \times 197)-197=38,612$.

18. http://www.therefugeeproject.org

19. http://migrationsmap.net/

20. https://www.iom.int/world-migration

21. It was shown for the first time in Paris from 21 November 2008 to 15 March 2009 at the Fondation Cartier pour l'art contemporain.

22. Lucify is a data visualisation agency based in Helsinki. Lucify, which means "to make lucid or clear", offers to "help" their customers visualise data in the form of interactive products, which are not necessarily cartographic. The visualisations proposed, developed for the Web, can be easily integrated on a website or a blog and the source codes of their visualisations are sometimes disseminated freely. According to the agency's website, several projects have been integrated into a number of online newspapers: The Guardian, The Atlantic, The Huffington Post, The Independent, Helsingin Sanomat and The Daily Mail. The two authors of the map co-founded the agency. Ville Saarinen works in communication and software development. According to the description provided on the agency's website, he spends a lot of time reflecting on how to combine sociology and technology. Juho Ojala describes himself as fascinated by communication and interested by dangerous ideas... The agency has produced other infographics on the same subject: http://www.lucify.com/

23. Nicolas Lambert (2015) Mer Morte (1993-2015) Carnet (néo)cartographique, http:// f.hypotheses.org/wp-content/blogs.dir/1381/files/2015/04/MerMorte.png

24. A first edition was published in 2009.

25. For example, the map of arbitrary detention sites of migrants in Morocco, designed and created in February 2015 by a member of the collective, Elsa Tyszler, is symptomatic of the challenge presented by cartography. For the first time, a map showed the minimum number of migrants detained in 18 cities in Morocco (schools, social centres, sports centres, etc.). It not only had an impact in several media, but also led the President of the Casablanca Administrative Tribunal to send a bailiff to several sites, in order to open an investigation. This followed a massive round-up by the Moroccan authorities in camps near the Spanish enclave of Melilla.

26. See for example, the maps of people subject to the administrative contradictions of the Dublin Convention, based on data produced by Eurostat (Migreurop, 2013, p. 60-63). 
27. The maps displayed on the (néo)cartographie website, at this address: http:// neocarto.hypotheses.org/1731, were also included in the publication coordinated by Anne-Laure Amilhat Szary and Frédéric Giraut (see Clochard and Lambert, 2015).

28. Hackitectura.net (2001-2012) is a collective of architects, programmers, artists and activists (Pablo Soto, Sergio Moreno, Jose Perez de Lama, etc.) dedicated to the study of moving bodies and electronic flows in emerging territories. See also their other projects: GISS (Stream Global Support independent, 2005-2007), Indymedia Detroit (2003-2007), Fadaiat (Tarifa-Tanger, 2004-2005), Emerging Géographies TCS2, Extremadura (2007) or Libertés Plaza, Sevilla (2005-2007).

29. k3000 includes Helmut Dietrich, Matthew Gaskins, Sophie Goltz, Nana Heidenreich, Sabine Hess, Sylvia Kafhesy, Serhat Karakayali, Astrid Kusser, Maureen Müller, Efthimia Panagiotidis, Susanna Perin, Peter Spillmann, Vassilis Tsianos, Michael Vögeli and Marion von Osten.

30. Moving Beyond Borders is a travelling exhibition produced by Migreurop and set up by the company Étrange Miroir.

31. A term in Maghrebi Arabic which means "burners", those who "burn" borders. The term "harragas" refers to migrants who attempt to cross the Mediterranean Sea from the shores of the Maghreb.

32. Artists: Marie Moreau, Lauriane Houbey and Fabien Fischer; Geographers: Sarah Mekdjian, and Anne-Laure Amilhat Szary; refugees and asylum seekers living in Grenoble: Laetitia Abbas, Alishum Ahmedin, Ahmedin A., Shamil Astahanov, Nasruddin Gladeema, Karim Huseynov, Issa Ibrahm Hamid, Fiston Massamba, Tatevik Melkonyan, Salomon Paluku, Aboubakar Souleiman Guelleh, Kanké Tounkara.

\section{ABSTRACTS}

Based on several conventional geography works and/or artistic works - some of them made by the authors of this paper -, this article focuses on how the mapping of international migrations has evolved since the beginning of the 1990s. The representation of migratory movements, which oscillates between arrows, measurements of stocks and different forms of design, implies both scientific and political stakes for the cartography and geography of migrations. After making a brief recalling of the changes that the mapping of migratory flows has experienced from its origins in the 19th century until today, the authors refer to the main technical and epistemological challenges that cartography of migratory movements and the presentations of itineraries raise nowadays. Finally the article analyses the new cartographic forms that have emerged since the beginning of the 2000s within the interconnected domains of sciences, arts, and militancy.

À partir de diverses réalisations conventionnelles en géographie et/ou artistiques, parmi lesquels des travaux réalisés par les auteurs, cet article s'intéresse à la manière dont la cartographie des migrations internationales a évolué depuis le début des années 1990. La représentation des mouvements migratoires, qui oscille entre des flèches, des mesures de stocks et diverses formes de dessin, soulève autant d'enjeux scientifiques et politiques posés à la cartographie et géographie des migrations. Après un bref rappel des changements qu'a connus la cartographie des flux migratoires, depuis ses origines, au XIXe siècle, jusqu'à aujourd'hui, les auteurs évoquent les principaux défis techniques et épistémologiques que les cartes de flux ou représentant des 
itinéraires ne cessent de poser. Puis pour terminer, sont présentées de nouvelles formes cartographiques, ayant émergé depuis le début des années 2000, dans les domaines croisés de la science, de l'art et du militantisme.

Partiendo de diversos trabajos convencionales de geografía y/o artísticos - algunos de ellos realizados por los propios autores -, este artículo pretende mostrar cómo la cartografía de las migraciones internacionales ha ido evolucionando desde principios de los años 1990. La representación de los movimientos migratorios, que abarca desde flechas, hasta medidas de reserva y diferentes formas de diseño, supone para la cartografía y la geografía de las migraciones toda una serie de retos, tanto científicos como políticos. Tras hacer un repaso de los cambios que ha ido experimentando la cartografía de los flujos migratorios desde sus orígenes en el siglo XIX hasta la actualidad, los autores presentan los principales retos técnicos y epistemológicos que los mapas de flujos y las representaciones de itinerarios continúan planteando en el momento actual. Por último, se presentan nuevas formas cartográficas surgidas a partir del 2000 que se inscriben en ámbitos interconectados como la ciencia, el arte y el activismo.

\section{INDEX}

Keywords: cartography, migratory flows, itinerary, arrows, migratory policies, European Union, artistic creation

Mots-clés: cartographie, flux migratoires, itinéraire, flèche, politiques migratoires, Union européenne, création artistique

Palabras claves: cartografía, flujos migratorios, itinerario, flechas, políticas migratorias, Unión Europea, creación artística

\section{AUTHORS}

\section{LUCIE BACON}

Geographer, PhD student, MIGRINTER (CNRS UMR 7301 - University of Poitiers), lucie.bacon.bih@gmail.com

\section{OLIVIER CLOCHARD}

Geographer, Research Fellow, CNRS, member of Migreurop, MIGRINTER (CNRS UMR 7301 -

University of Poitiers, olivier.clochard@univ-poitiers.fr

\section{THOMAS HONORÉ}

Cartographer, inCittà, thomas.honore82@gmail.com

\section{NICOLAS LAMBERT}

Cartographer, member of Migreurop, joint research unit, RIATE, Paris Diderot University, nicolas.lambert@ums-riate.fr

\section{SARAH MEKDJIAN}

Geographer, teacher and researcher, PACTE, Grenoble Alpes University, sarah.mekdjian@univgrenoble-alpes.fr 
PHILIPPE REKACEWICZ

Cartographer, Visionscarto, rekacewi@online.no

TRADUCTEUR_DESCRIPTION

ALEXANDRA POMEON (TRANSLATION)

Kalex Translations 